\title{
HAEMATOLOGICAL AND HISTOLOGICAL BONE MARROW FINDINGS IN EXPERIMENTAL CLASSICAL SWINE FEVER
}

\author{
N. L. CALDERÓN ${ }^{1}$, L. H. PAASCH ${ }^{2}$, J. BOUDA ${ }^{3}$ \\ 1,2 Department of Avian Production, Faculty of Veterinary Medicine and Animal Science. \\ National Autonomous University of Mexico, 04510 Mexico, D. F. \\ ${ }^{3}$ Department of Clinical Diagnosis, Faculty of Veterinary Medicine and Animal Science. \\ National Autonomous University of Mexico, 04510 Mexico City.
}

Received February 24, 1997

Accepted November 4, 1997

\begin{abstract}
Calde rón N. L., L.H.Pa a ch, J. B ou da: Haematological and Histological Bone Marrow Findings in Experimental Classical Swine Fever. Acta vet. Brno 1997, 66: 171-176.

Aiming to shed more light on the pathogenesis of acute haemorrhagic diathesis in Classical Swine Fever (CSF), studies on hemostatic parameters were performed to evaluate blood coagulation pathways as well as determinations of blood cells counts with special emphasis on platelets in 16 pigs experimentally infected with the classical swine fever virus and in four control pigs. The aforementioned studies were complemented with histological evaluation of bone marrow of the same animals.

In this study no significant changes were determined in the variables of intrinsic and extrinsic coagulation pathways, however, a significant reduction of platelet counts was detected starting at the third day post infection.

The histological findings consisted in swelling and vacuolation of megakaryocytes observed in the bone marrow at the second day post infection, at four days post infection the megakaryocytes were necrotic. Other outstanding changes were detected in the vascular endothelium after the third day post infection, consisting in severe swelling and necrosis of endothelial cells.

Thus, thrombocytopenia and endothelial damage are considered the basic causes of haemorrhagic diathesis. It is presumed that thrombocytopenia results from a direct viral damage to megakaryocytes.

Coagulation disorders, at least in early stages of the disease, are not involved as causative factors of haemorrhagic diathesis.
\end{abstract}

Classical swine fever, disseminated intravascular coagulation, haemorrhagic diathesis

The extensive formation of microthrombi in arterioles and capillaries is known as disseminated intravascular coagulation (DIC). This condition is often detected in severe systemic diseases in which the coagulation system is activated. During DIC, blood platelets and clotting factors are depleted and despite that the fibrinolytic system is activated, excess fibrine can not be properly removed (Müller-Berhaus 1989; Cotran et al. 1990; Meyers and Wardrop 1991). In cases of DIC, haemorrhagic diathesis is frequently a consequence and clinical findings include thombocytopenia. hypofibrinogenemia, prothrombinemia and decreased plasmatic values of factors V and VIII (Meyers and Wardrop 1991; Bythell 1993). Viral diseases that cause an extensive endothelial damage may induce DIC. Endothelial necrosis exposes subendothelial connective tissue that acts as a platelet aggregation surface and also necrotic cells liberate thomboplastine and other procoagulant substances (Debbie and Abelseth 1971; Bick 1988; Robinson and Grant Max ye 1993). Clasical swine fever (CSF) is a viral disease of swine characterized by an haemorrhagic diathesis and extensive necrosis of endothelial cells ( Te r p s t r a 1991).

It is considered that in acute CSF several disorders of the coagulation system are present and besides multiple hemorrhages also disseminated thrombosis can be detected mainly in the spleen, kidneys and liver ( $\mathrm{Tr}$ a u t we in 1988). 
The thrombi might be considered as an evidence of consumptive coagulopathy, however, it has been also demonstrated that thrombocytopenia plays an important role in the pathogenesis of haemorrhagic diathesis in CSF not related to DIC (He ene et al. 1971; Hoffmann et al. 1971).

It is important to emphasize that in acute CSF thombocytopenia can be detected in early stages before disseminated thrombosis takes place, of significance is also the fact that CSF virus can be recovered from bone marrow samples in natural infections ( $\mathrm{He}$ e ne et al. 1971; Hof $\mathrm{fmann}$ et al. 1971). The aforementioned data suggest that platelet precursors in bone marrow could be affected by CSF virus causing thrombocytopenia.

In summary, it is generally accepted that haemorrhages in CSF are the result of direct viral vascular damage complicated by consumptive coagulopathy. However, considering that thrombocytopenia is detectable in CSF before any evidence of coagulation disorders, it is important to emphasize the study of a possible direct effect of the virus on thrombopoiesis and/or platelets.

Therefore the aims of the present study were to evaluate the intrinsic and extrinsic coagulation pathways to determine possible consumptive coagulopathy and relating this findings whith sequential determination of platelet counts. Simultaneously, histological studies of bone marrow were conducted to detect a possible thrombopoietic damage.

\section{Materials and Methods}

The studies were performed in 20 crossbred, six-to-eight week old pigs obtained from farms free of CSF. In every case absence of antibodies againts CSF virus was corroborated by serum neutralizing test. Sixteen pigs were infected by a single intramuscular dose of $10^{6} \mathrm{TCID}_{50}$, CSF virus, Ames Iowa strain. The remaining 4 pigs were used as controls. Clinical signs and rectal body temperature were recorded daily during the experiment.

Haematological studies

Blood samples were obtained daily from six infected animals and two controls during eight consecutive days. Pigs were sampled in such an order that a single animal was not bled the following day. For each sample the following determinations were performed:

a) White blood cell count

b) Differential white blood cell count

c) Platelet count

d) Activated partial thromboplastin time (APTT)

e) Prothrombin time (PT)

f) Thrombin time (TT).

The, coagulation tests were performed with commercial kits (Instrumentation Laboratory, USA).

Histological studies

Bone marrow samples of each pig were obtained of two infected animals daily during eight consecutive days. Control samples were obtained from four non infected pigs simultaneously the eight day. Tissues were fixed in buffered $10 \%$ formaline $\mathrm{pH} 7.2$ embedded in paraffin and 4 micrometer thick sections were stained with hematoxyline-eosine and the Wright method.

\section{Results}

All the inoculated pigs became febrile at day 1 post infection. Other clinical signs appeared progressively after the onset of fever and included anorexia, apathy, diarrhea, vomit, incoordination and skin erythema.

Platelet cell counts were slightly increased 1-2 days post infection, on the following days there was a significant reduction, 3-5 days post infection a reduction of $47.28 \%$ was detected, compared with counts of normal pigs. Platelet cell counts 6-8 days post infection had a reduction of $78 \%$ (Fig. 1). 
Fig. 1

Platelet counts of control and infected pigs. (Reference values [Duncan and Prasse 1986] 2-5 $\times 10^{11 / L}$ Standard deviation is presented as line on the bars

\section{CELLS $\times 10^{\circ} / \mathrm{L} \quad$ CONTROLS}

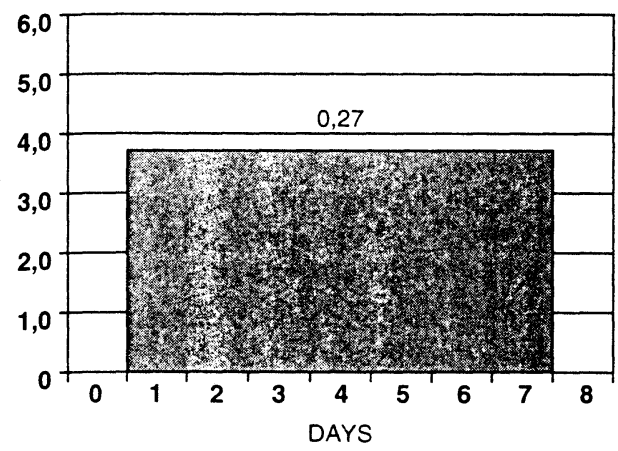

CELLS $\times 10^{11 / L}$ INFECTED

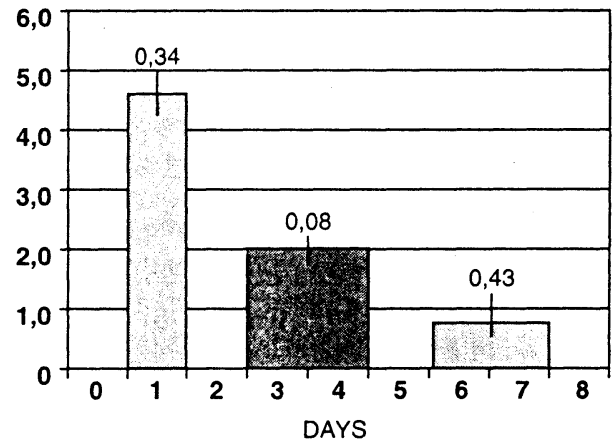

Fig. 2

White Blood Cell (WBC) counts of control and infected pigs.

(Reference values [Duncan and Prasse 1986] 11-22 $\times 10^{9} / \mathrm{L}$

Standard deviation is presented as line on the bars

\section{CELLS $\times 10^{\circ} \mathrm{L} \quad$ CONTROLS}

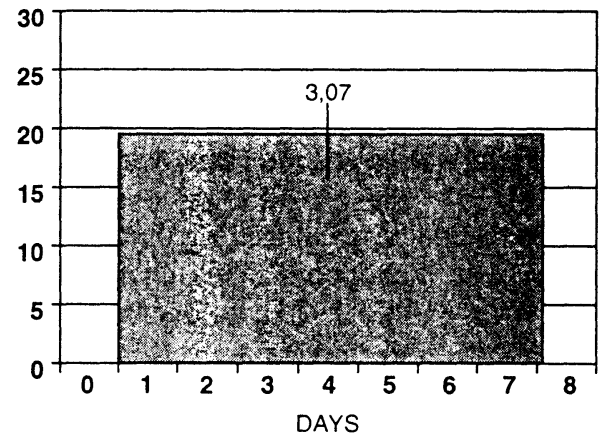

CELLS $\times 10^{\circ} \mathrm{L} \quad$ INFECTED

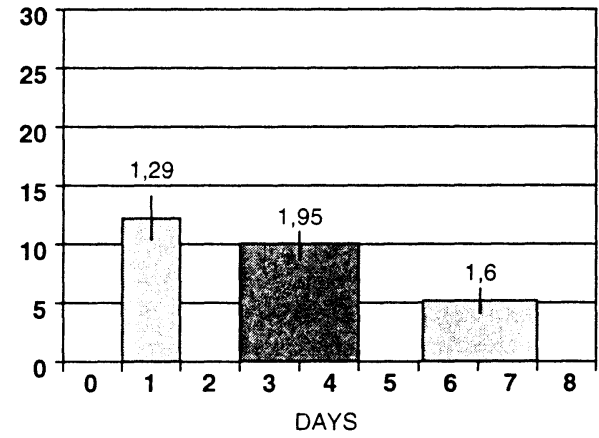

Fig. 3

Percentage of neutrophils of white blood cell count in controls and infected pigs.

(Reference values [Duncan and Prasse 1986] 20-70\%

Standard deviation is presented as line on the bars
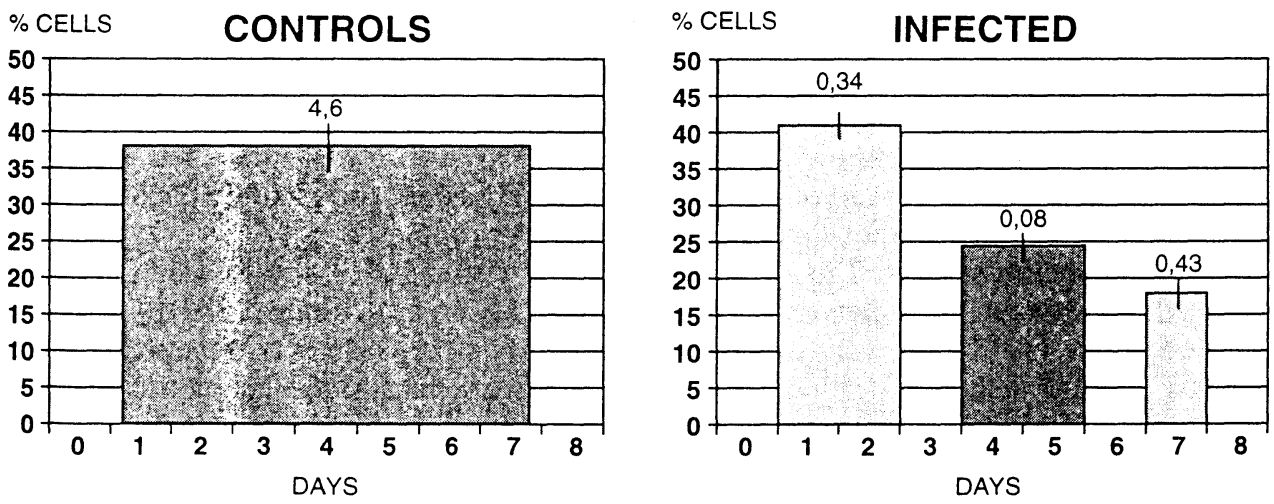
White blood cell counts had a significant reduction day 1 post infection $(\mathrm{P}<0.001)$ (Fig. 2). Maximal values of $72 \%$ reduction were detected days $6-8$ post infection.

Lymphocytic cell counts were increased $38 \%$ in comparison to the values in control pigs at day 6 post infection.

Regarding the neutrophil cell counts a slight increase was detected 1-3 days post infection. A count reduction of $35 \%$ was determined 4-6 days post infection. A reduction of 50\% was detected 7-8 days post infection (Fig. 3).

Values of packed cell volume, hemoglobin, plasma proteins and fibrinogen were in the range of references values in pigs.

Regarding the intrinsic and extrinsic coagulation pathways the following parameters, consisting in APTT, PT and TT, had no deviations from normal values established for the species, and from those obtained for the control pigs.

Histological findings in the bone marrow day 2 post infection consisted of depletion of the granulocytic cell lines and swelling and vacuolation of megakaryocytes, see Plate XIII. Fig. 4. Day 4 post infection the granulocytic cell line depletion was severe and megakaryocytes were necrotic (Fig. 5). Haematopoietic bone marrow was affected by multiple focal necrosis. There was also an extensive swelling of endothelial cells with fibrinoid necrosis of vessel walls (Plate XIV., Fig. 6).

\section{Discussion}

The clinical signs detected in the infected pigs of the present study were consistent with those described in the literature for acute CSF ( T rautwe in 1988; D ahle and Liess 1992), except that in our experimental animals the onset of fever was detected at day 1 post infection, while in the consulted reports the pigs became febrile at day 2 . In this regard it is important to consider that several viral strains and field isolates use to show variations in virulence and pathogenicity (V a n Oirschot 1988).

As described in the results of our present study, the haematological finding that appeared at the onset of fever, the first day post infection was leukopenia. This characteristic haematological finding in CSF is recorded by Dunne $(1963,1973)$, as occurring even before the first rise in temperature.

Heene et al. (1971) had similar results as those reported in our study regarding the progressive decrease in platelet counts with the lowest levels between post inoculation days 6 to 8 .

In the pathogenesis of the disease, the early and progressive significant reduction in white cell and platelet counts is consistent with the results of sequential bone marrow biopsies which show a progressive degeneration of entire cell population ( Hoffmann et al. 1971b).

In our study progressive degeneration of megakaryocytes was evident two days post infection and at day 4 post infection the entire cell population was depleted and megakaryocytes were necrotic.

The aforementioned megakaryocyte destruction could be direct effect of CSF virus on this cell population. Further studies should corroborate this hypothesis.

It is of comparative interest that in African Swine Fever (ASF), viral particles can be clearly demonstrated in platelets and megakaryocytes (Edwards et al. 1985).

He e ne et al. (1971) found that in course of acute CSF, multiple defects of the coagulation systems can be detected at final stages of the disease and since haemorrhages and disseminated thrombosis are simultaneously present, a consumptive coagulopathy might be suggested as a pathogenic mechanism of the haemorrhagic diathesis. 
In our study, however, general parameters that evaluate intrinsic and extrinsic coagulation pathways remained normal during the study.

Since an extensive swelling of the endothelial cells with fibrinoid necrosis of vessel walls was simultaneously present with megakaryocyte necrosis, it is considered that thrombocytopenia and endothelial damage are the basic causes of haemorrhagic diathesis, in acute classical swine fever.

\section{Hematologické a histologické nálezy v kostní dřeni při experimentálním klasickém moru prasat}

Cílem práce bylo přispět $\mathrm{k}$ objasnění patogeneze akutní hemoragické diatézy při klasickém moru prasat na základè studia hemostatických ukazatelů na zvířecím modelu pro vyhodnocení kaskád krevní koagulace, jakož i buněčných krevních elementů se zaměřením na krevní destičky na 16 pokusných prasatech infikovaných virem klasického moru prasat a 4 kontrolních prasatech. Studie byla doplněna histologickým vyhodnocením kostní dřeně $\mathrm{z}$ těchto zvířat.

V této studii nebyly zjištěny signifikantní změny v ukazatelích extrinsické a intrinsické koagulace, avšak celkový počet krevních destiček byl významně snížen, počínaje 3 . dnem po infekci.

Histologické změny byly charakterizovány zduřením a vakuolizací megakaryocytů v kostní dřeni 2 . den po infekci, nekróza megakaryocytů byla zjištěna 4 . den po infekci. Další významné změny byly zjištěny 4 . den po infekci v endotelu cév, spočivající v intenzivním zduření a nekróze endoteliálních buněk.

Trombocytopénie a poškození endotelu jsou považovány za hlavní příciny hemoragické diatézy. Předpokládáme, že trombocytopénie vzniká $\mathrm{v}$ dủsledku prímého poškození megakaryocytů virem. Poruchy koagulace, zejména $v$ první fázi onemocnění, nejsou prričinou hemoragické diatézy.

\section{References}

BICK, R. L. 1988: Disseminated intravascular coagulation and related syndromes: A clinical review. Semin. Thromb. Hemostasis. 14: 299-338

BITHELL, T. L. 1993: Acquired coagulation disorders. In: Wintrobe's clinical hemathology, Vol. 2. 9th ed. Philadelphia: Lea and Febiger. pp. 1473-1510

COTRAN, R. S., KUMAR, V., ROBBINS, S. L. 1994: Diseases of red cells and bleeding disorders. In: Pathologic basis of disease, 5th ed. Philadelphia: W. B. Saunders Company, pp. 623-627

DAHLE, J., LIESS, B. 1992: A review on classical swine fever infections in pigs: Epizootiology, clinical disease and pathology. Comp. Immun. Microbiol. infect. Dis. 15: 203-211

DEBBIE. J. G., ABELSETH. M. K. 1971: Pathogenesis of epizootic hemorrhagic diseases. I. Blood coagulation during viral infection. J. Infect. Dis. 124: 217-222

DUNCAN, J. R., PRASSE, K. W. 1986: Veterinary laboratory medicine, 2nd ed. Iowa State University Press.

DUNNE, H. W. 1963: Field and laboratory diagnosis of hog cholera. Vet. Med. 53: 222-239

DUNNE, H. W. 1973: Hog cholera (European swine fever). Adv. Vet. Med. 17: 315-359

EDWARDS, J. F., DODDS. W. J., SLAUSON, D. O. 1985: Megakaryocytic infection and thrombocytopenia in African swine fever. Vet. Pathol. 22: 171-176

HEENE, D., HOFFMANN-FEZER, G., HOFFMANN, R., WEISS, E., MÜLLER-BERGHAUS, G., LASCH, H. G. 1971: Gerinnungsstörungen bei akuter Schweinepest. Beitr. Pathol. Bd. 144: 259-271

HOFFMANN, R., HOFFMANN-FEZER, G., KIMETO, B., WEISS, E. 1971a: Mikrothromben als morphologischer Ausdruck einer Verbrauchskoagulopathie bei akuter Schweinepest. Zbl. Vet. Med. B 18: $710-718$

HOFFMANN, R., HOFFMANN-FEZER, G., WEISS, E. 1971b: Knochenmarksveränderungen bei akuter Schweinepest mit besonderer Berücksichtigung der thrombopoetischen Zellen. Berl. Münch. Tierärztl. Wschr. 84: 301-305

MEYERS, K. WARDROP, K. J. 1991: Acquired or complex coagulation disorders. Disseminated intravascular 
coagulation. In: Advances in veterinary science and comparative medicine, Vol. 36 (S. M. Cotter ed.), Academic Press Inc. pp. 131-136

MÜLLER-BERGHAUS, G. 1989: Pathophysiologic and biochemical events in disseminated intravascular coagulation: Dysregulation of procoagulant and anticoagulant pathways. Semin. Thromb. Hemostasis. 15: $58-87$

ROBINSON, W. F., GRANT MAXIE, M. 1993: The cardiovascular system. In: Pathology of domestic animals, Vol. 3. 4th ed. (K. V. F. Jubb, P. C. Kennedy and N. Palmer, eds.), Academic Press, Inc. pp. 62-64

TERPSTRA, C. 1991: Hog cholera: An update of present knowledge. Br. Vet. J. 147: 397-406

TRAUTWEIN, G. 1988: Pathology and pathogenesis of the diseases. In: Classical swine fever and related infections (B. Liess, ed.), Boston: Martinus Nijhoff Nordrecht. pp. 28-54

VAN OIRSCHOT, J. T. 1988: Description of the virus infection. In: Classical swine fever and related infections (B. Liess, de.), Boston: Martinus Nijhoff Nordrecht. pp. 1-25

Adress for correspondence:

Dr. Norma L. Calderón

Department of Avian Production

Faculty of Veterinary Medicine and Animal Science

National Autonomous University of Mexico

04510 Mexico, D. F.

E-mail: nlca@servidor.unam.mx 
Plate XIII.

Calderón N. C. et al.: Haematological... pp.171-176

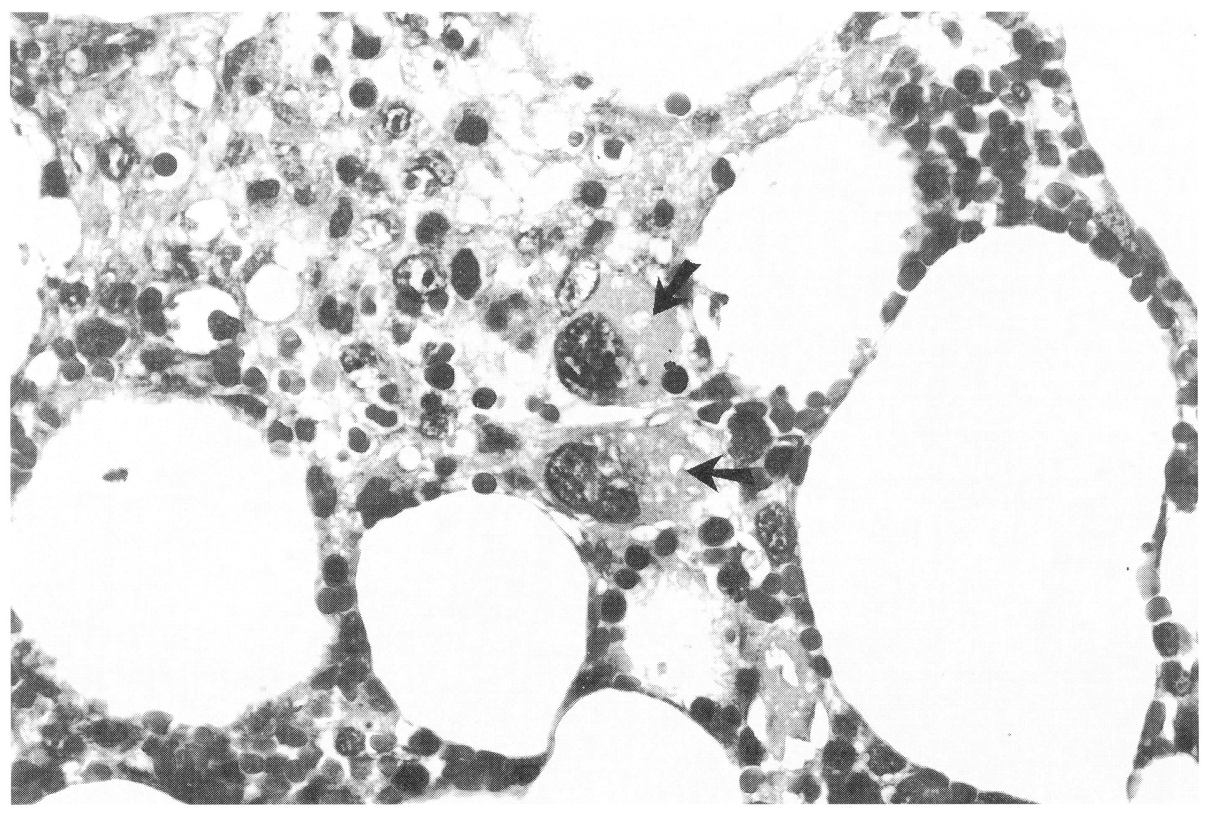

Fig. 4. Megakaryocyte with cytoplasmic vacuolation in the bone marrow of a pig at day 2 post infection. $\mathrm{HE}, \times 1000$.

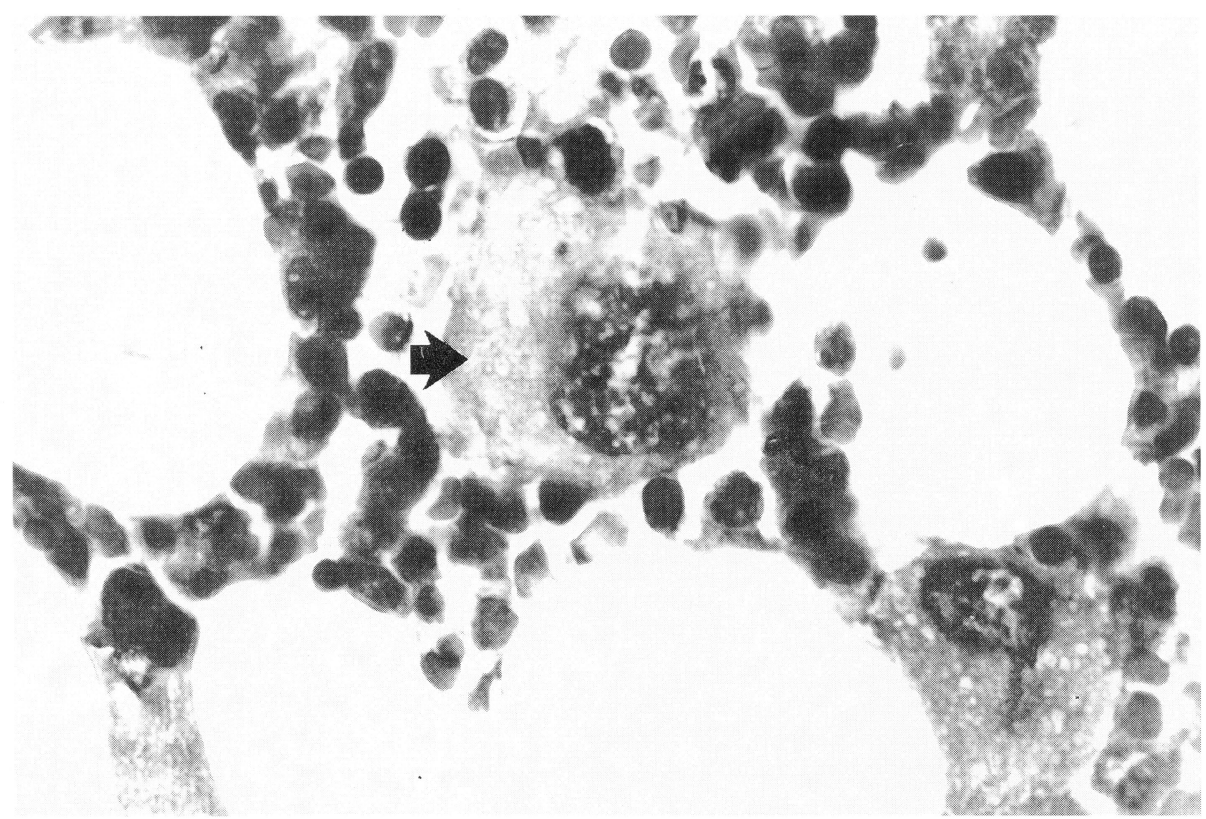

Fig. 5. Cellular depletion in the bone marrow of a pig at day 4 post infection. A necrotic megakaryocyte is observed in the center of figure (arrow). HE, $\times 400$. 


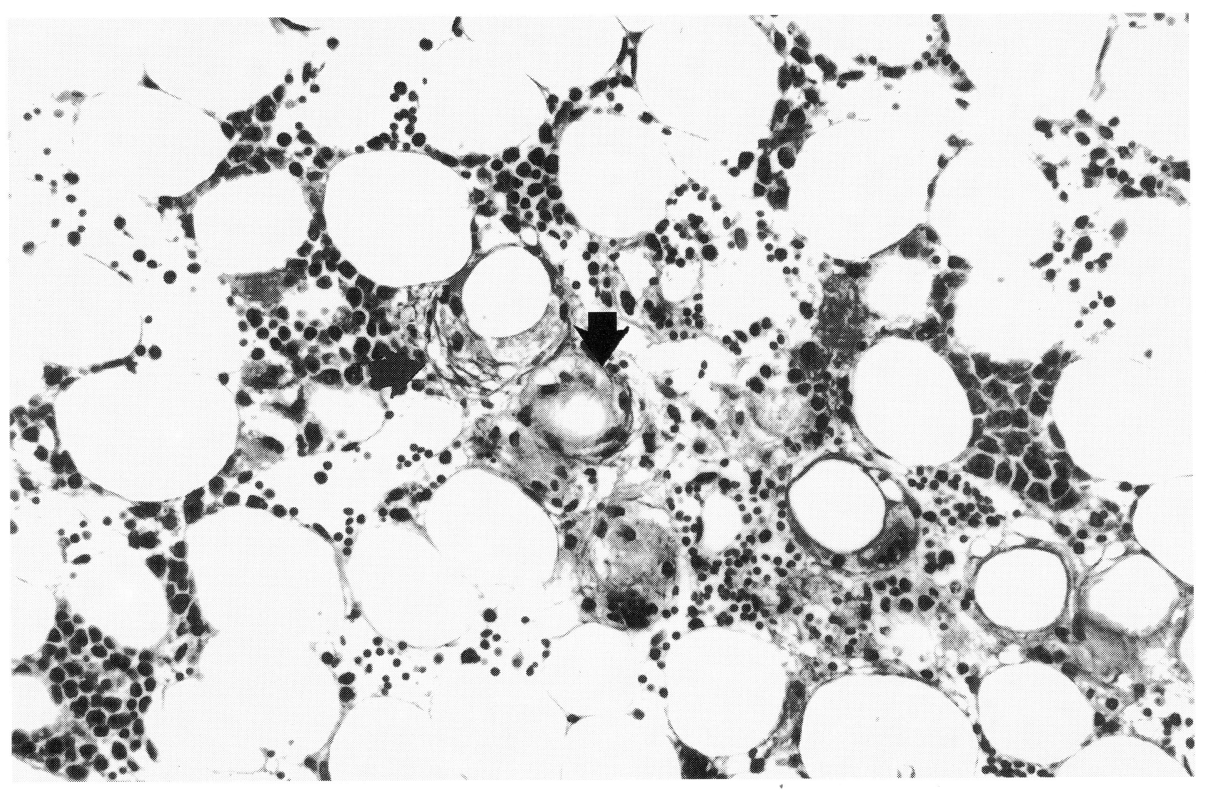

Fig. 6. Fibrinoid degeneration of vessel walls in the bone marrow of a pig at day 4 post infection (arrows). $\mathrm{HE}, \times 400$. 